TEACHING : Jurnal Inovasi Keguruan dan IImu Pendidikan

Vol. 1. No. 4 Desember 2021 e-ISSN : 2775-7188 | p-ISSN : 2775-717X

\title{
UPAYA MENINGKATKAN HASIL BELAJAR PESERTA DIDIK DENGAN MENERAPKAN MODEL PROBLEM BASED LEARNING
}

\author{
INDAH QORIANA \\ SMPN 4 Mataram \\ e-mail: qorianabaik@gmail.com
}

\begin{abstract}
ABSTRAK
Penulisan artikel ini bertujuan untuk mengetahui apakah penggunaan metode Problem Based Learning dapat meningkatkan hasil belajar dan motivasi peserta didik kelas VII-6 di SMPN 4 Mataram pada Mapel Informatika khususnya pada materi Algoritma dan Pemrograman. Pada pelaksanaannya, rendahnya hasil belajar peserta didik disebabkan karena beberapa faktor antara lain metode pembelajaran yang dipakai kurang bervariasi, peserta didik kurang serius dalam mengikuti proses pembelajaran. Model Problem Based Learning diterapkan dengan alasan model pembelajaran ini mampu meningkatkan rasa ingin tahu,rasa percaya diri, kreatifitas peserta didik,sehingga dapat melatih kemampuan peserta didik dalam memecahan suatu masalah.Adapun proses pelaksanaannya peserta didik yaitu peserta didik disajikan suatu masalah, peserta didik mendiskusikan dalam sebuah masalah kecil kemudian mengidentifikasi apa yang mereka butuhkan untuk menyelesaikan masalah.kemudian peserta didik saling bertukar informasi melalui peer teaching atas masalah tertentu dan menyajikan solusi atas masalah. Terakhir peserta didik mereview apa yang mereka pelajari dari proses pengerjaan selama ini. Metode Penelitian yang digunakan untuk penelitian ini adalah penelitian tindakan kelas dengan model spiral dengan melalui beberapa siklus tindakan dan terdiri dari empat komponen yaitu perencanaan (Planning), pelaksanaan (Action), observasi (Observation), dan refleksi(Reflection). Dari hasil penelitian ternyata diperoleh hasil di akhir siklus pada siklus II pertemuan II, adalah hasil belajar peserta didik mengalami peningkatan yaitu mendapatkan nilai rata-rata sebesar 80, 15 , hasil observasi peserta didik mencapai skor rata-rata sebanyak 4,51. Ini berarti indikator keberhasilan yaitu sebesar $\geq 4,0$ dan KKM sebesar $\geq 75$ telah terlampaui.
\end{abstract}

Kata kunci : model pembelajaran, hasil belajar

\section{ABSTRACT}

The writing of this article aims to determine whether the use of the Problem Based Learning method can improve learning outcomes and motivation of students in grades VII-6 at SMPN 4 Mataram in the Information Technology Department, especially on Algorithm and Programming material. In practice, the low learning outcomes of students are caused by several factors, including the learning methods used are less varied, students are less serious in participating in the learning process. The Problem Based Learning model is applied on the grounds that this learning model is able to increase students' curiosity, self-confidence, creativity, so that they can train students' abilities in solving a problem. As for the implementation process, students are presented with a problem, students discuss in a small problem then identify what they need to solve the problem. Then students exchange information through peer teaching on certain problems and present solutions to problems. Finally, students review what they have learned from the process so far. The research method used for this research is a spiral research model through several cycles of action and consists of four components, namely planning, action, observation, and reflection. From the results of the study, it turned out that at the end of the cycle in the second cycle of the second meeting, the student learning outcomes had increased, namely getting an average score of 80.15 , the results of student observations reached an average score of 4.51. This means that the success indicators of 4.0 and KKM 75 have been exceeded.

Keywords: learning model, learning outcomes 


\section{PENDAHULUAN}

Perkembangan zaman yang semakin canggih, peran teknologi sangat dibutuhkan untuk mencapai sasaran dan peningkatan mutu pendidikan. Apalagi di era revolusi industri 4.0 diperlukan pendidikan yang dapat membentuk generasi kreatif, inovatif dan kompetitif. Tujuan pendidikan pada dasarnya adalah membentuk sumber daya manusia yang berkualitas, pada pelaksanaannya proses pembelajaran masih cenderung konvensional, seperti menjelaskan materi , meghafal materi. Hal semacam ini hanya akan menciptakan komunikasi satu arah jika peserta didik tidak aktif bertanya. dan dampaknya dapat mempengaruhi hasil belajar peserta didik. Oleh karena itu guru dituntut untuk dapat mencari metode pembelajaran yang tepat untuk dapat meningkatkan motivasi belajar peserta didik.

Dalam Proses belajar pasti ada tujuan yang ingin dicapai, ada beberapa hal yang yang menjadi tujuan dalam belajar yaitu : Ranah Kognitif, berkenaan dengan hasil belajar intelektual tang terdiri dari enam aspek yang meliputi pengetahuan,pemahaman,aplikasi,analisis,sintesis, dan evaluasi., Ranah Afektif berkenaan dengan sikap terdiri dari lima aspek yang meliputi penerimaan,jawaban,penilaian, organisasi dan internalisasi.Ranah Psikomptorik, berkenaan dengan hasil belajar yang berupa keterampilan dan kemampuan bertindak, meliputi enam aspek yaitu gerakan refleks, keterampilan gerak dasar, kemampuan perceptual, ketepatan, keterampilan kompleks, dan gerakan ekespresif dan interaktif (Sudjana)

Berdasarkan Permendikbud No. 35 Tahun 2018, Pemerintah akhirnya resmi menjadikan Mapel Informatika sebagai Mapel Pilihan di kurikulum 2013, dimana SMPN 4 Mataram menjadi salah satu sekolah pilihan yang melaksanakan Mapel Informatika dan mulai berjalan Pada Tahun Pelajaran 2019/2020.Konsep Mata Pelajaran berbeda dengan Mapel TIK (Teknologi Informasi Dan Komunikasi). Mapel Informatika tidak hanya mempelajari beragam perangkat lunak komputer tetapi juga mengajak peserta didik untuk memecahkan masalah,dan membuat aplikasi dengan berpikir kritis .

Algoritma dan pemrograman adalah jantung dari pemahaman mengenai pemrograman atau pembuatan sebuah program, berdasarkan hasil observasi di kelas VII-6 di SMPN 4 Mataram dari hasil penilaian terlihat bahwa hasil belajar kognitif peserta didik kurang maksimal, ternyata materi ini dianggap sulit oleh peserta didik, pada pertemuan pertama Nilai rata-rata ujian tulis adalah 66.78 , dan pertemuan ke dua 70.60 dari hasil pengamatan dapat disimpulkan bahwa hasil penilaian masih dibawah indikator keberhasilan yaitu sebesar $\geq 75.00$. menghadapi permasalahan tersebut peneliti berupaya untuk meningkatkan hasil belajar peserta didik dengan menggunakan model Pembelajaran Problem Based Learning.

Menurut Duch dalam Shoimin Pengertian Problem Based Learning adalah model pembelajaran yang bercirikan adanya permasalahan nyata sebagai konteks untuk para peserta didik belajar berfikir kritis dan keterampilan memecahkan masalah serta memperoleh pengetahuan. Ciri-ciri model pembelajaran Problem Based Learning adalah kegiatan belajar mengajar dimulai dengan pemberian sebuah masalah, masalah yang disajikan berkaitan dengan kehidupan nyata para peserta didik ,mengorganisasikan masalah seputar disiplin ilmu, peserta didik diberi tanggung jawab yang maksimal dalam membentuk maupun menjalankan proses belajar secara langsung, peserta didik dibentuk manjadi beberapa kelompok kecil, peserta didik dituntut mendemonstrasikan produk atau kinerja yang telah mereka pelajari. Model Pembelajaran ini cocok diterapkan pada materi Algoritma dan Pemrograman, karena peserta didik dituntut untuk dapat berpikir, kreatif, inovatif, dan mampu menyelesaikan masalah.

\section{METODE PENELITIAN}

Penelitian tindakan Kelas ini mengacu pada pendekatan spiral yang merupakan empat langkah kesatuan yang berulang yaitu : Perencanaan (Planning),pelaksanaan (Action), pengamatan (Observation), dan pemikiran kembali (Reflection) (Arikunto)..Keempat langkah ini dilakukan secara berualng-ulang sampai perbaikan yang diharapkan tercapai. Penelitian dilaksanakan dalam 2 Siklus.Dalam setiap siklus berisikan kegiatan-kegiatan nyata yang akan dilaksanakan. Kegiatan pada setiap tahap dapat dijelaskan sebagai berikut : Tahap 
Perencanaan (Planning) terdiri dari menyusun RPP(Rencana Pelaksanaan Pembelajaran) dengan menerapkan model Problem Base Learning, menyiapkan sumber bahan dan semua alat yang digunakan dalam penelitian, menyusun lembar observasi guru dan dan lembar observasi peserta didik, menyusun alat evaluasi. Untuk penyusunan alat evaluasi menggunakan panduan/pedoman pengolahan nilai hasil penelitian sebagai berikut :

a. Observasi Guru

$$
S a=\frac{\text { Perolehan skor }}{\text { JumlahAspekyang diamati }}
$$

b. Observasi Peserta didik

$$
S a=\frac{\text { Perolehan skor }}{\text { JumlahAspekyang diamati }}
$$

c. Hasil Belajar Peserta didik

$$
\begin{aligned}
& \mathrm{Na}=\frac{\text { PerolehanSkor }}{\text { Skor Maksimal }} \times 100 \\
& \text { Keterangan : } \\
& \mathrm{Sa}=\text { Skor Akhir } \\
& \mathrm{Na}=\text { Nilai Akhir }
\end{aligned}
$$

Tahap Pelaksanaan (Action) terdiri dari guru menyampaikan materi pasa peserta didik, guru menugaskan kepada peserta didik untuk membentuk kelompok, guru menyampaikan tugas kepada peserta didik dalam bentuk lembar kerja, kelompok melakukan diskusi untuk menghasilkan solusi dari pemecahan masalah, setiap kelompok melakukan presentasi dalam bentuk karya yang dihasilkan, kelompok lain melakukan apresiasi, mengakhiri pembelajaran dengan melakukan kesimpulan atau merangkum sesuai masukan yang diperoleh kelompok lain. Tahap Observasi, observasi merupakan kegiatan yang dilakukan oleh observer, Adapun kegiatan yang dilakukan adalah sebagai berikut : Observasi Guru (Observation),dilakukan oleh teman sejawat sebagai Observer sekaligus sebagai pembimbing guru dalam melaksanakan PTK, Observasi Peserta didik dilaksanakan oleh Guru Mata Pelajaran sekaligus sebagai peneliti daalan Penelitian Tindakan Kelas pada kegiatan diskusi Kelompok. Tahap Refleksi (Reflection) pada tahapan ini guru melakukan kegiatan akhir berupa renungan hasil perolehan data, Pengolahan hasil analisa dan penelitian, mencocokkan hasil analisa data dengna indikator keberhasilan, dan rencana perbaikan tindak lanjut.

\section{HASIL DAN PEMBAHASAN}

\section{Hasil}

\section{SIKLUS I}

Hasil Proses belajar mengajar yang dilakukan guru dengan menggunakan Model Problem Base Learning pada Siklus I baik Pertemuan I dan Pertemuan II adalah sebagai berikut :

a. Observasi Guru

Hasil skor rata -rata Observasi pada siklus I pertemuan I adalah 3,14 sedangkan pada pertemuan II mendapatkan skor rata adalah 3,57.sementara indikator keberhasilan yang diharapkan adalah $\geq 4.0$, ini berarti pada siklus ini Guru belum mampu menerapkan model Pembelajaran Problem Based Learning secara optimal.

b. Observasi Peserta Didik

Hasil Observasi peserta didik dalam peningkatan aktivitas pembelajaran dan hasil belajar diperoleh skor rata - rata pada pertemuan I yaitu 3.03 dan pada pertemuan II adalah 3.45, sedangkan indikator keberhasilan yang diharapkan adalah $\geq 4.0$, ini berarti perolehan skor ratarata hasil observasi peserta didik pada Siklus ini belum memenuhi kriteria yang diharapkan.

Dampak dari belum menigkatnya aktivitas pembelajaran dapat dilihat dari nilai rata-rata tugas dan nilai rata-rata hasil tes peserta didik, yaitu pada pertemuan I adalah 65,82 , dan pertemuan II adalah 69,18 dimana nilai- nilai tersebut masih dibawah standar KKM yaitu $\geq 75$. 
TEACHING : Jurnal Inovasi Keguruan dan IImu Pendidikan

Vol. 1. No. 4 Desember 2021 e-ISSN : 2775-7188 | p-ISSN : 2775-717X

Tabel 1. Hasil Siklus I

\begin{tabular}{|c|l|c|c|c|c|}
\hline \multirow{2}{*}{ No } & \multirow{2}{*}{ Jenis Kegiatan } & \multirow{2}{*}{$\begin{array}{c}\text { Indikator } \\
\text { Keberhasilan }\end{array}$} & \multicolumn{2}{|c|}{$\begin{array}{c}\text { Perolehan } \\
\text { (Rata-Rata) }\end{array}$} & \multirow{2}{*}{ Keterangan } \\
\cline { 4 - 5 } & & & I & II & \\
\hline 1 & Observasi Guru & $\geq 4,00$ & 3,14 & 3,57 & Belum Tuntas \\
\hline 2 & Observasi Peserta didik & $\geq 4,00$ & 3,03 & 3,45 & Belum Tuntas \\
\hline 3 & Nilai Tugas & $\leq 75,00$ & 65,82 & & Belum Tuntas \\
\hline 4 & Nilai Tes Tertulis & $\leq 75,00$ & & 69,18 & Belum Tuntas \\
\hline
\end{tabular}

Ket : observasi guru dan dan peserta didik dinyatakan tuntas jika skor $\geq 4.0$

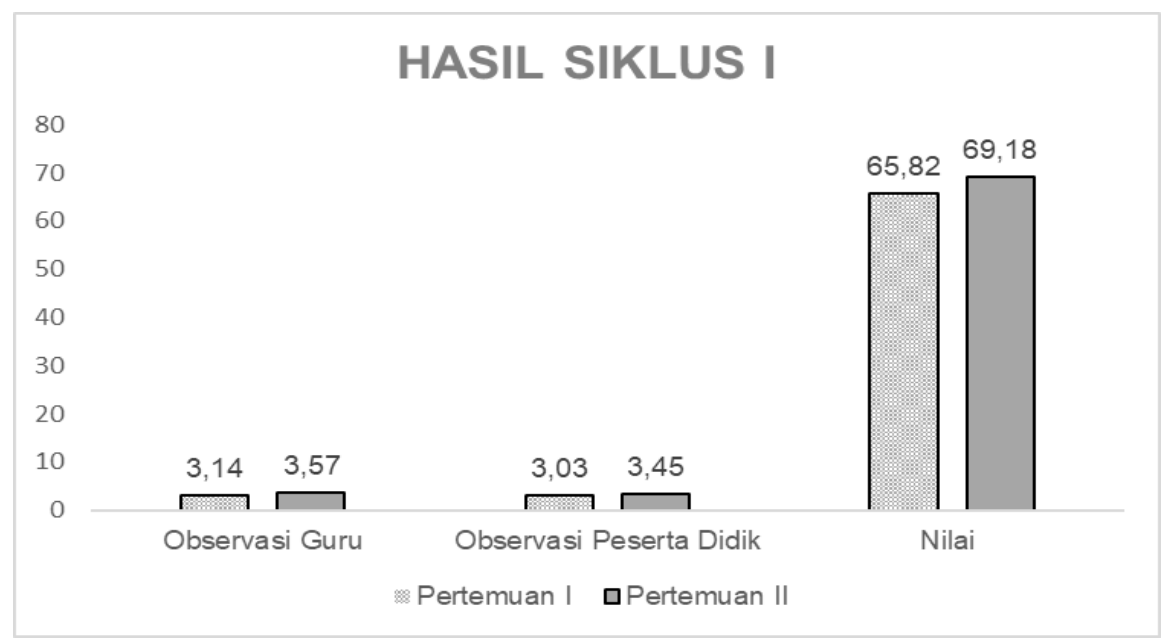

\section{Gambar 1. Grafik Hasil Siklus I}

Mengingat indikator keberhasilan pada siklus I belum tercapai, maka penelitian tindakan kelas akan di lanjutkan pada Siklus II , dengan persiapan yang lebih baik lagi dengan harapan proses pembelajaran dengan menggunakan Problem Based Learning dapat lebih optimal , sehingga metode ini terbukti berhasil meningkatkan kualitas aktivitas dan hasil belajar peserta didik kelas VII-6 Semester Satu Tahun Pelajaran 2019/2020 di SMPN 4 Mataram.

\section{SIKLUS II}

Dari Hasil Proses Pembelajaran Siklus II baik pertemuan I dan II diperoleh Data Sebagai berikut:

a. Observasi Guru

Hasil Observasi guru pada Siklus II pada petemuan I memperoleh skor rata-rata 4,07 dan pertemuan II meperoleh skor rata-rata 4,50, ini berarti proses pembelajaran pada siklus ini sudah dapat memenuhi bahkan melampaui indikator keberhasilan yaitu $\geq 4,0$.

b. Observasi Peserta Didik

Selaras dengan hasil observasi guru, hasil observasi peserta didik juga mengalami peningkatan, pada pertemuan I skor rata-rata diperoleh 4,12 dan pada pertemuan ke II diperoleh skor rata-rata 4,51, sementara indikator keberhasilan adalah $\geq 4.0$ ini berarti perolehan skor rata-rata telah melampauai indikator keberhasilan.

Proses pembelajaran dikatakan berhasil jika hasil belajar peserta didik meningkat, indikasinya dapat dilihat dari perolehan rata-rata nilai tugas dan test tertulis masing-masing yaitu 76,52 dan 80,15, ini berarti sudah melampaui nilai $\mathrm{KKM} \geq 75$. 
TEACHING : Jurnal Inovasi Keguruan dan IImu Pendidikan Vol. 1. No. 4 Desember 2021 e-ISSN : 2775-7188 | p-ISSN : 2775-717X

\begin{tabular}{|c|l|c|c|c|c|}
\hline \multirow{2}{*}{ No } & \multirow{2}{*}{ Jenis Kegiatan } & \multirow{2}{*}{$\begin{array}{c}\text { Indikator } \\
\text { Keberhasilan }\end{array}$} & \multicolumn{2}{|c|}{$\begin{array}{c}\text { Perolehan } \\
\text { (Rata-Rata) }\end{array}$} & \multirow{2}{*}{ Keterangan } \\
\cline { 4 - 5 } & & & I & II & \\
\hline 1 & Observasi Guru & $\geq 4,00$ & 4,07 & 4,50 & \multirow{2}{*}{ Tuntas } \\
\hline 2 & Observasi Peserta didik & $\geq 4,00$ & 4,12 & 4,51 & Tuntas \\
\hline 3 & Nilai Tugas & $\leq 75,00$ & 76,52 & & Tuntas \\
\hline 4 & Nilai Tes Tertulis & $\leq 75,00$ & & 80,15 & Tuntas \\
\hline
\end{tabular}

Ket : observasi guru dan dan peserta didik dinyatakan tuntas jika skor $\geq 4.0$

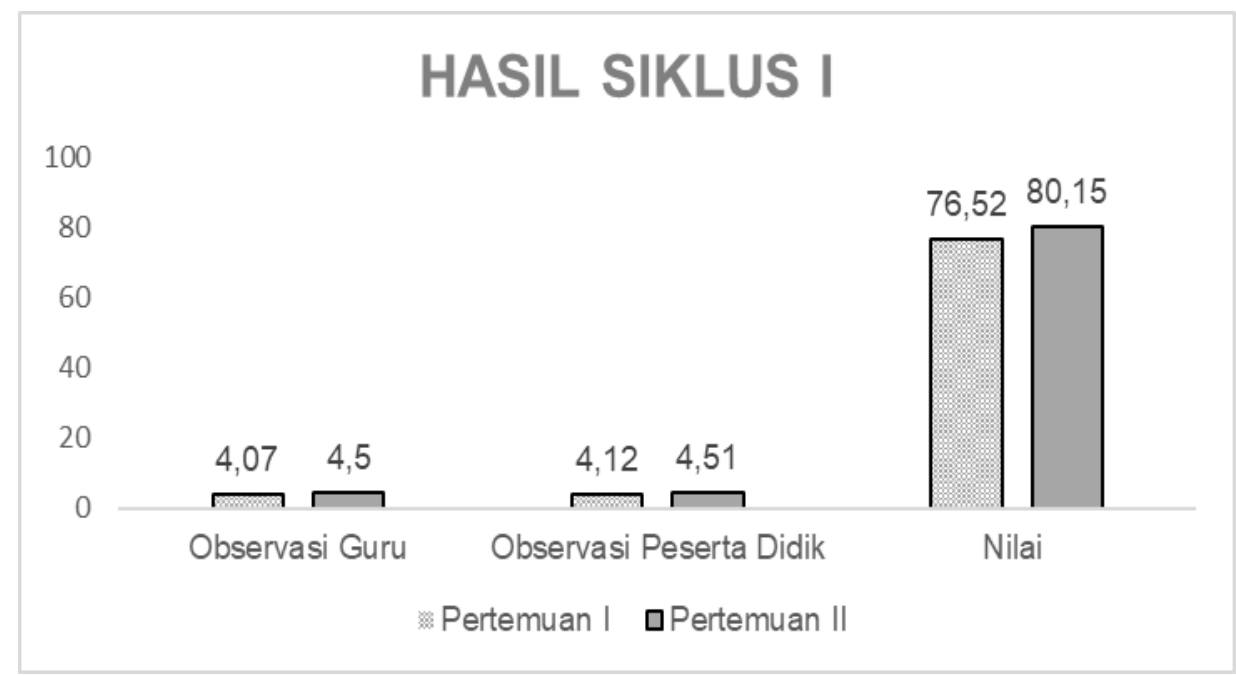

Gambar 2. Grafik Hasil Siklus II

Berdasarkan data tersebut diatas, akhirnya penulis memutuskan bahwa penelitian tidak perlu dilanjutkan lagi pada siklus berikutnya , karena semua indikator keberhasilan sudah terpenuhi.

\section{Pembahasan}

Berdasarkan Hasil data yang didapatkan Pada Siklus I baik pertemuan I dan II memperoleh skor rata-rata 3.45 dari indikator yang ditetapkan yaitu $\geq 4.0$ dan termasuk kategori cukup hal tersebut mengindikasikan bahwa proses pembelajaran dengan menggunakan metode Problem Base Learning belum mencapai target yang diinginkan.Oleh Karena itu Penelitian dilanjutkan Pada Siklus II. Agar hasil pembelajaran mencapai target yang diinginkan maka proses pembelajaran dengan menggunakan metode Problem Based Learning perlu dievaluasi , apa saja kekurangan - kekurangan yang perlu diperbaiki, trik-trik apa saja yang harus dikuasai sehingga pelaksanaannya lebih optimal.

Pada Siklus II peneliti berupaya mencari kelemahan-kelemahan pada proses pembelajaran Siklus I, yaitu dengan melihat kembali skenario pembelajaran dengan menggunakan Metode Problem Based Learning. Pada Siklus II peneliti berupaya memperbaiki proses pembelajaran dengan cara memperbaiki cara penyampaian materi agar kebih mudah dipahami peserta didik, dan mengoptimalkan kegiatan-kegiatan diskusi kelompok dan berupaya agar semua peserta didik lebih aktif dalam kegiatan diskusi . Berdasarkan Data Hasil Siklus II terlihat bahwa peserta didik mulai terbiasa dengan Metode Pembelajaran Problem Based Learning. Karena Semua Indikator keberhasilan telah terpenuhi maka kegiatan penelitian hanya sampai siklus ke II.Hasil ini penelitian diperkuat dengan pendapat (Rifandis), (Danang), (Reza) bahwa pembelajaran Problem Based Learning dapat meningkatkan hasil belajar peserta 
didik. Karena model pembelajaran ini dapat membantu peserta didik dalam menyelesaian masalahnya.

Pengertian Belajar adalah suatu proses usaha yang dilakukan individu untuk memperoleh suatu perubahan tingkah laku yang baru secara keseluruhan , sebagai hasil pengalaman individu itu sendiri dalam interaksi dalam lingkungannya. (Drs. Slameto). Sebelum kegiatan penelitan pembelajaran hanya terpusat pada guru dengan menggunakan metode ceramah , nilai rata-rata peserta didik belum mencapai KKM. Selama kegiatan Penelitan dengan menggunakan Model Pembelajaran Problem Based Learning ada beberapa kemajuan yang ditemukan pada peserta didik antara lain peserta didik dapat menjadi lebih aktif dan kritis dalam menyelesaikan masalah, Lebih aktif dalam kegiatan kelompok, sehingga pembelajaran tidak terasa membosankan, disamping itu model Problem Based Learning . Penelitian ini juga diperkuat juga oleh (Shoimin) bahwa keunggulan model Problem Based Learning melatih peserta didik secara berkelompok dapat menyelesaikan aktifitas belajar dengan menggunakan sumbersumber pengetahuan baik dari perpusatakaan, internet,wawancara dan observasi dari lingkungan sekitar untuk memecahkan sebuah masalah.Selain itu Model Problem Based Learning dapat melatih peserta didik untuk melakukan komunikasi ilmiah dalam bentuk presentasi dan diskusi.

\section{KESIMPULAN}

Penerapan pendekatan Problem Based learning terbukti sangat efektif dalam upaya meningkatkan aktivitas dan hasil belajar Informatika peserta didik kelas VII-6, semester satu Tahun Pelajaran 2019/2020 di SMPN 4 Mataram. Dari data pada Tabel tersebut diatas bahwa hasil skor rata-rata pada Siklus II baik pertemuan I dan Pertemuan II sudah melampaui indikator keberhasilan yaitu $\geq 4.0$ dan KKM sebesar $\geq 75$. Oleh karena itu Penelitian dinyatakan "Berhasil" dan dihentikan pada Siklus II.

\section{DAFTAR PUSTAKA}

Arikunto,S. (2003). Prosedur Penelitian Suatu Pendekatan Praktek, Edisi V. Jakarta :Rineka Cipta

Aris Shoimin. (2014). Model Pembelajaran Inovatif Dalam Kurikulum 2013, Yogyakarta Ar.Ruzz Media

Drs. Slameto. (2003). Belajar dan Faktor-faktor Yang Mempengaruhinya, Jakarta: Rineka Cipta

Giyantoro, Reza Adi. (2013). Penerapan Model Pembelajaran Problem Based Learning Pada Mata Diklat Las Kelas X TPM SMK Taman Siswa Surabaya. Jurnal Pendidikan Teknik Mesin.

Nana Sudjana. (1999). Penilaian Hasil Proses Belajar Mengajar, Bandung, PT. Remaja Rosdakarya

Priyasudana, Danang. (2016). Penerapan Model Pembelajaran Problem Based Learning (PBL) Pada Mata Pelajaran Mekanika Teknik Untuk meningkatkan Hasil Belajar Siswa Kelas X Teknik Permesinan SMK Negeri 3 Boyolangu, Tulungagung, Jurnal Pendidikan Teknik Mesin.

Sulkhin, Rifandis. (2006). Penerapan Model Problem Based Learning(PBL) Pada Mata Pelajaran Gambar dan Konstruksi Bangunan Kelas XI TGB SMK Negeri 1. Mojokerto, Jurnal Kajian Pendidikan Teknik Bangunan 